\title{
A novel and simple cell-based detection system with a collagen-encapsulated B-lymphocyte cell line as a biosensor for rapid detection of pathogens and toxins
}

\author{
Pratik Banerjee ${ }^{1}$, Dominik Lenz ${ }^{2}$, Joseph Paul Robinson², Jenna L Rickus ${ }^{3}$ and Arun K Bhunia
}

Cell-based biosensors (CBBs) are becoming important tools for biosecurity applications and rapid diagnostics in food microbiology for their unique capability of detecting physiologically hazardous materials. A multi-well plate-based biosensor containing B-cell hybridoma, Ped-2E9, encapsulated in type I collagen matrix, was developed for rapid detection of viable cells of pathogenic Listeria, the toxin listeriolysin $\mathrm{O}$, and the enterotoxin from Bacillus species. This sensor measures the alkaline phosphatase release from infected Ped-2E9 cells colorimetrically. Pathogenic L. monocytogenes cells and toxin preparations from $L$. monocytogenes or B. cereus showed cytotoxicity ranging from 24 to $98 \%$ at $3-6 \mathrm{~h}$ postinfection. In contrast, nonpathogenic L. innocua (F4247) and B. subtilis induced minimal cytotoxicity, ranging only 0.4-7.6\%. Laser scanning cytometry and cryo-nano scanning electron microscopy confirmed the live or dead status of the infected Ped2E9 cells in gel matrix. This paper presents the first example of a cell-based sensing system using collagen-encapsulated mammalian cells for rapid detection of pathogenic bacteria or toxin, and demonstrates a potential for onsite use as a portable detection system.

Laboratory Investigation (2008) 88, 196-206; doi:10.1038/labinvest.3700703; published online 3 December 2007

KEYWORDS: cell-based sensor; collagen entrapment; Listeria monocytogenes; Bacillus cereus; Ped-2E9 cells; rapid diagnostics

Detection of biological entities using cell-based assays (CBAs) has already found its niche in biomedical research as well as in clinical, environmental, and bioprocess industries. ${ }^{1-5}$ The rapid detection methodologies applicable to these fields using CBAs have had enormous impact on the emergence of cellbased biosensors (CBBs). ${ }^{5-8}$ In a $\mathrm{CBB}$, the normal physiological response of a living cell or cellular component resulted by one or more external factors (stimuli) is recorded. ${ }^{9,10}$ This 'response' can be qualitatively or quantitatively analyzed to deduce the nature and character of the external 'stimuli, ${ }^{5,6,8-11}$ In some of these CBBs the sensing elements could be the vegetative cells of bacteria, ${ }^{5,12}$ or eukaryotic ${ }^{13}$ or mammalian cells. ${ }^{8,14,15}$ Different types of platforms or materials have been used to 'pattern' or lay different types of higher eukaryotic cells to design cell-based sensors. ${ }^{5,10,16-20}$ Interfacial engineering to couple biological cell (or cellular components) to signal transducers or detection platforms is critical for successful cell-based biosensing. ${ }^{21-24}$ The types of materials used for immobilization and entrapment of living cells vary widely, encompassing biocompatible polymers (such as polyethylene glycol, alginate, synthetic peptides or silica gel $)^{25-28}$ to biologically derived substances such as collagen or fibronectin, to name a few. ${ }^{29,30}$

The viability of the living cell after immobilization determines the actual working life of the sensor. For that reason, materials that best mimic the actual physiological conditions would be the most effective material to use as a matrix for cell harboring. Cellular entrapment in biomaterials such as collagen has distinct advantages, including the unparalleled biocompatibility of collagen, which makes it one of the most versatile biomaterials used for tissue culture known so far. ${ }^{31,32}$ In addition, collagen gel can be prepared with different pore sizes that trap different size cells by varying the concentration. ${ }^{33,34}$ Collagen gel has high mechanical strength and has excellent gelling properties. ${ }^{33}$ Three-dimensional (3D) encapsulation of different cell types in collagen gel has become a standard method in tissue engineering applications. ${ }^{31,32}$ Application of mammalian cells

\footnotetext{
${ }^{1}$ Molecular Food Microbiology Laboratory, Department of Food Science, Purdue University, West Lafayette, IN, USA; ${ }^{2}$ Purdue University Cytometry Laboratory and the Bindley Bioscience Center, Purdue University, West Lafayette, IN, USA and ${ }^{3}$ Department of Agriculture and Biological Engineering and Weldon School of Biomedical Engineering, Purdue University, West Lafayette, IN, USA

Correspondence: Professor AK Bhunia, PhD, Molecular Food Microbiology Laboratory, Department of Food Science, Purdue University, 745 Agriculture Mall Drive, West Lafayette, IN 47907, USA. E-mail: Bhunia@purdue.edu
} 
in collagen-entrapped form for use as biosensors is still in its infancy, ${ }^{34,35}$ but offers significant promise. ${ }^{34-36}$ Previous studies from our laboratory have shown that a mouse B-cell hybridoma (Ped-2E9)-based cytotoxicity assay can be used to detect the presence of pathogenic Listeria species and the enterotoxins from Bacillus species. ${ }^{16,37,38}$ This cytotoxicity assay can also differentiate the presence of viable pathogenic Listeria species from nonpathogenic ones. ${ }^{16,39-42}$

Adherent and nonadherent mammalian cell lines of various tissue origins were used previously to distinguish differential cytotoxic response of virulent Listeria species from avirulent ones. ${ }^{16,43-45}$ The cytotoxic properties were determined by monitoring the changes in cell morphology, ${ }^{42}$ formation of plaques in a monolayer, ${ }^{43,45}$ or dye uptake due to loss of membrane permeability. ${ }^{44}$ The drawbacks of many of these assays are prolonged assay time (16-24 h) and lack of quantitative data; thus, they are undesirable for incorporation into biosensor platform for detection of Listeria. In contrast, the Ped-2E9 cell-based cytotoxicity assay for biosensing has several advantages: cells are highly sensitive to cytotoxin, thus the cell-based assay is very rapid $(1-6 \mathrm{~h}),{ }^{39,46,47}$ and provides both quantitative as well as qualitative information about the presence of pathogens or toxins. This assay measures the activity of enzymes such as alkaline phosphatase (ALP) or lactate dehydrogenase released by the hybridoma cells infected with pathogen or toxins ${ }^{16,37-39,46,47}$ making the Ped-2E9-based assay a robust assay system that can easily be integrated into an automated sensing platform. The rapid detection of viable pathogenic Listeria species and enterotoxin from Bacillus from food, clinical and environmental samples are important from commercial and biosecurity perspectives.

In this paper, we report a new design fabrication mode of a portable CBB platform using collagen-encapsulated Ped-2E9 cells for rapid detection of pathogenic Listeria and Bacillus species and the toxins from these organisms. By applying a novel method using laser scanning cytometry we determined that the bacteria- or toxin-mediated death of gel-entrapped mammalian cells can be directly correlated to an analytical cytotoxicity assay.

\section{MATERIALS AND METHODS}

\section{Reagents and Biochemicals}

Type I collagen (rat tail, collagen-I) was purchased from BD Bioscience (San Jose, CA, USA). Dulbecco's modified Eagle's mediums with phenol red (DMEM) or without phenol red (DMEM-phenol red free, DMEM-PRF) were purchased from Invitrogen (Carlsbad, CA, USA). Fetal bovine serum (FBS) was obtained from Atlanta Biologicals (Norcross, GA). Fluorescence dyes, propidium iodide (PI), Hoechst 33342, acridine orange $(\mathrm{AO})$ and a ready-to-go ALP liquid substrate were purchased from Sigma-Aldrich (St Louis, MO, USA). All media and reagents for bacteriological growth studies were purchased from Difco Laboratories (Sparks, MD, USA).

\section{Preparation of Collagen Gel}

Collagen type I gels were prepared by mixing appropriate volumes of collagen solution with $10 \times$ phosphate-buffered saline $(10 \times$ PBS, Hyclone, UT, USA) and $1 \mathrm{~N} \mathrm{NaOH}$ in precooled eppendorf tubes. The final concentrations of the collagen in the gel matrix were varied from 0.7 to $2.5 \mathrm{mg} / \mathrm{ml}$ to obtain an appropriate collagen sieve diameter. An average diameter of 5-7 $\mu \mathrm{m}$ is considered as optimal for the present application (average bacterial diameter, $2 \mu \mathrm{m}$ and Ped-2E9 cell diameter, $10 \mu \mathrm{m})$. After addition of the reagents the gel solutions were kept at $37^{\circ} \mathrm{C}$ for $15-30 \mathrm{~min}$ to complete the gelation.

\section{Determination of Gel Matrix Pore Size by Cryo-Scanning Electron Microscopy}

To determine the pore size of the gel matrix sieves (with different collagen concentrations from 0.7 to $2 \mathrm{mg} / \mathrm{ml}$ ), we performed a cryo-scanning electron microscopy (SEM) analysis with minimal dehydration of the gel matrix. The gel preparations were mounted on a slit holder and plunged into liquid nitrogen slush. A vacuum was pulled and the samples were transferred to the Gatan Alto 2500 (Pleasanton, CA, USA) prechamber (cooled to approximately $-60^{\circ} \mathrm{C}$ ). After the samples were cut with a microtome with a cold knife, the samples were sublimated at $-85^{\circ} \mathrm{C}$ for $30 \mathrm{~min}$ followed by sputter coating for $100 \mathrm{~s}$ with platinum. The samples were then transferred to the microscope cryostage (approximate temperature: $-130^{\circ} \mathrm{C}$ ) for imaging. The SEM images were taken with an FEI NOVA nanoSEM (FEI, Hillsboro, OR, USA) using ET and TLD detectors operating at $5 \mathrm{kV}$ accelerating voltage, with approximately $6 \mathrm{~mm}$ working distance and the magnifications were varied between $\times 2500$ and $\times 50000$.

\section{Mammalian Cell Culture}

Lymphocyte origin murine Ped-2E9 cells $^{39}$ were routinely cultured in DMEM supplemented with $10 \%$ FBS $(\mathrm{DMEM}+\mathrm{FBS})$ at $37^{\circ} \mathrm{C}$ in $7 \% \mathrm{CO}_{2}$. Liquid-nitrogen-stored Ped-2E9 cells (passage numbers between 5 and 10) were suspended at a ratio of 1:10 in DMEM + FBS and grown for $72 \mathrm{~h}$. Ped-2E9 cells were passaged again in DMEM with or without phenol red supplemented with $2.5 \% \mathrm{FBS}^{16}$ in T-25 and T-75 flasks (Nunc, Denmark) until cells reached to the logarithmic phase of growth (usually $72 \mathrm{~h}$ ) after which they were used for experiments.

Encapsulation of Ped-2E9 Hybridoma Cells in Gel Matrix The general approach of encapsulating the Ped-2E9 cells in collagen gel for biosensing is described in Figure 1. Logphased grown Ped-2E9 cells were collected, counted, washed, and about $2.5 \times 10^{7}$ viable cells $/ \mathrm{ml}$ were resuspended in complete serum-free medium (SFM). The cell suspension was mixed with neutralized type I collagen (final $\mathrm{pH}$ was adjusted approximately to 7 by adding $1 \mathrm{~N} \mathrm{NaOH}$ ) at a final concentration of $1.5 \mathrm{mg}$ collagen $/ \mathrm{ml}$. A volume of 30-100 $\mu \mathrm{l} /$ 


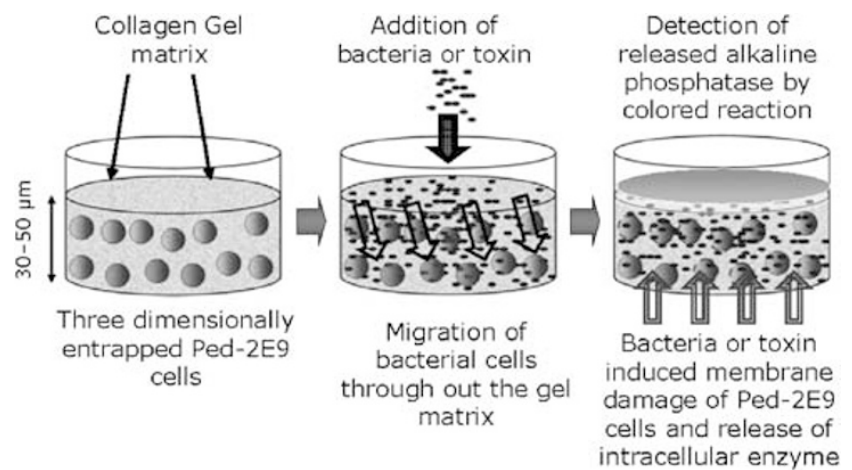

Figure 1 Strategy for cell-based biosensing using collagen-encapsulated Ped-2E9 hybridoma cells. Schematic design of the gel-entrapped Ped-2E9 cell in multi-wells and the assay procedure.

well of cell suspensions in collagen were dispensed in 96- or 48-well plates to obtain a gel thickness of $30-50 \mu \mathrm{m}$, respectively, and the plates were maintained at $37^{\circ} \mathrm{C}$ for $15-30 \mathrm{~min}$ to form a firm gel. The gel thickness of 30-50 $\mu \mathrm{m}$ was used throughout this study because the laser scanning cytometer (LSC), which was used to verify the viability of collagen-trapped Ped-2E9 cells, has a vertical scanning (penetration) depth range of 30-50 $\mu \mathrm{m}$. DMEM-PRF with $2.5 \%$ FBS was added to each well and the plates were maintained at $37^{\circ} \mathrm{C}$ in a humidified incubator with $7 \% \mathrm{CO}_{2}$.

Viability of the collagen-suspended cells was enumerated and recorded at every $24 \mathrm{~h}$ for a period of 5 days by Trypan blue (TB) dye $(0.4 \%)$ exclusion test or with incorporation of fluorescence dyes, Hoechst and PI. For enumeration of viability using $\mathrm{TB}$, the cells were dislodged by treating the collagen matrix by $100 \mu \mathrm{g} / \mathrm{ml}$ Clostridium histolyticum collagenase (Sigma) for $30 \mathrm{~min}$ at $37^{\circ} \mathrm{C}$. The dislodged cells were then incubated with $0.4 \% \mathrm{~TB}$ solution for $1-3 \mathrm{~min}$. The hybridoma cells were counted using an inverted light microscope (Olympus, Tokyo, Japan). The viable cells excluded the dye whereas the nonviable ones took up the dyes and appeared blue.

\section{Laser Scanning Image Cytometry}

Image cytometry was used ${ }^{48}$ to evaluate the absolute count and the percentage of viability of the gel-encapsulated Ped2E9 cells in situ. The live or dead cell counts were obtained directly from gel matrix without physical disruption of the collagen gel. Briefly, a $50 \mu \mathrm{l}$ of mixed dye (containing $50 \mu \mathrm{g} /$ $\mathrm{ml} \mathrm{PI}$ and $20 \mu \mathrm{g} / \mathrm{ml}$ Hoechst) was added directly to the wells of a 96-well plate (Costar 3603, Corning, NY, USA) containing collagen-encapsulated Ped-2E9 cells and incubated for $1 \mathrm{~h}$ at $37^{\circ} \mathrm{C}$. Subsequently, the wells were washed twice with SFM, and after the second wash, $50 \mu$ lof SFM was added to each well containing gel-encapsulated cells and the laser scanning image cytometry (LSC) analysis of live/dead cell counts were performed with an iCys research imaging cytometer (CompuCyte, Cambridge, MA, USA). This instrument is based on an inverted fluorescent microscope and enables the quantitative analysis of adherent or immobilized cells. $^{48,49}$

For the current analysis, the nuclei of both, viable and dead cells were stained using Hoechst 33342 and were excited using a violet laser $(405 \mathrm{~nm})$. The nuclei of nonviable (dead) cells were exclusively stained using PI and excited with an Argon laser $(488 \mathrm{~nm})$. Both PI and Hoechst were used as parameter for identifying gel-encapsulated cells in 96-well assay plates. Within each well an area of $2500 \mu \mathrm{m}^{2}$ was analyzed, yielding a sufficient cell count for a statistical comparison.

\section{Bacterial Cultures and Toxin}

Frozen stock of Listeria monocytogenes strains Scott A (serotype 4b), V7 (serotype 1/2a) and L. innocua F4247; Bacillus cereus strains (A926, MS1-9, F4810) and B. subtilis were grown in brain heart infusion (BHI) broth at $37^{\circ} \mathrm{C}$ and subcultured twice. Fresh cultures $(1 \mathrm{ml}$ each) were centrifuged $(13000 \mathrm{~g}$ for $10 \mathrm{~min})$ at room temperature. The cell pellets were washed twice in filter sterilized (filter pore size $0.45 \mu \mathrm{m}$ ) cell phosphate-buffered saline (C-PBS, $0.14 \mathrm{M}$ $\mathrm{NaCl}, 5 \mathrm{mM} \mathrm{KCl}, 3 \mathrm{mM} \mathrm{Na} \mathrm{HPO}_{4}, 4 \mathrm{mM} \mathrm{NaH}{ }_{2} \mathrm{PO}, 10 \mathrm{mM}$ glucose ( $\mathrm{pH}$ 7.2)), or in presterilized serum-free DMEM-PRF and resuspended in $1 \mathrm{ml}$ of C-PBS or in DMEM-PRF, respectively.

Crude toxins from Bacillus species, prepared from bacterial cell-free culture supernatants as described previously, ${ }^{37}$ were used for cytotoxicity assays immediately or stored at $4{ }^{\circ} \mathrm{C}$ for not more than $48 \mathrm{~h}$.

Listeria cultures were grown in $50 \mathrm{ml}$ of BHI broth treated with $0.5 \%$ charcoal for $24 \mathrm{~h}$ at $37^{\circ} \mathrm{C}$ under shaking conditions (140 r.p.m.). Cells were pelleted by centrifugation and the cell-free supernatant was filter-sterilized $(0.45 \mu \mathrm{m})$ and was concentrated to $1 \mathrm{ml}$ using a $50-\mathrm{kDa}$ cutoff membrane in Amicon protein concentrator (Millipore, Bedford, MA, USA). The presence of listeriolysin O (LLO) protein was confirmed by SDS-PAGE analysis and by examining the zone of hemolysis on sheep blood agar plate (BD-BBL, Franklin Lakes, NJ, USA). The protein concentrations of the Bacillus crude toxin preparation and LLO were determined by using a Bio-Rad protein assay kit following the manufacturer's protocol (data not shown).

\section{Measurement of Cytotoxicity}

Collagen-I-encapsulated Ped-2E9 cells were grown for different incubation times $(24-96 \mathrm{~h})$ in 48 or 96-well plates. Spent medium from each well was aspirated without disturbing the gel and resuspended in serum-free DMEM-PRF. The cytotoxicity effects of bacterial cells or the toxin preparations on collagen-encapsulated Ped-2E9 cells were measured by an ALP release assay as described previously. ${ }^{40}$ Briefly, $50-100 \mu$ l of bacteria cell suspension $\left(1 \times 10^{9} \mathrm{CFU} /\right.$ $\mathrm{ml}$ ) or crude toxin preparations $(\sim 20 \mu \mathrm{g} / \mathrm{ml}, 50-100 \mu \mathrm{l})$ were added to each well of the 96- or 48-well microtiter plate, respectively, and held at $37^{\circ} \mathrm{C}$ in a humidified incubator with 
$7 \% \mathrm{CO}_{2}$ for a period of $3-6 \mathrm{~h}$. The supernatant from the 48-well plate was collected, centrifuged ( $1800 \mathrm{~g}$ for $5 \mathrm{~min}$ ) and placed in a mini-cuvette containing a ready-to-go ALP liquid substrate (Sigma). The color development was recorded at 3-5 min intervals at absorbance of $405 / 595 \mathrm{~nm}$ using a handheld USB2000 mini-spectrophotometer (Ocean Optics, Dunedin, FL, USA). For direct measurement of cytotoxicity on plates, a $100-\mu \mathrm{l}$ of ALP liquid substrate (Sigma) was added to each well of 96-well plate and were read after 3-5 min of incubation at room temperature at absorbance of $405 / 595 \mathrm{~nm}$ using a Bio-Rad plate reader (Hercules, CA, USA). The plates were further incubated at $37^{\circ} \mathrm{C}$ for about $5-15 \mathrm{~min}$ to observe for the development of a visible yellow color (positive cytotoxicity). The percent values of cytotoxicity were obtained by a formula described earlier. ${ }^{16,40}$

To confirm the functional significance of the choice of optimal concentration of collagen $(1.5 \mathrm{mg} / \mathrm{ml}$ with an approximate gel sieve or pore diameter of 6-7 $\mu \mathrm{m}$, as per our SEM data) for encapsulation of the Ped-2E9 cell and for the cytotoxicity assay, we tested two different concentrations of collagen, one lower $(1 \mathrm{mg} / \mathrm{ml}$ with an approximate diameter of $9-10 \mu \mathrm{m})$ and one higher $(2 \mathrm{mg} / \mathrm{ml}$ with an approximate pore diameter of $1-2 \mu \mathrm{m})$. Also, to asses how the different multiplicity of infections (MOIs) ratio of L. monocytogenes may affect the Ped-2E9 cell cytotoxicity results, two lower MOIs (50:1 and 10:1) were tested along with the 100:1 ratio, at 3 and $6 \mathrm{~h}$ postinfection time points. Furthermore, a comparison of two-dimensional (2D) conventional Ped-2E9 cell assay ${ }^{16,37-40}$ was done with the three-dimensionally encapsulated Ped-2E9 cells in collagen matrix to assess whether 3D encapsulated system produces similar assay results. We also performed cryo-SEM analysis with infected hybridoma cells following the same procedures mentioned above.

LSC analysis was carried out in 96-well plates following the same procedure as described above for viability measurement. A parallel TB live-dead count (described earlier in the present article) was taken in duplicate 96-well plates for comparisons with the live-dead counts obtained from LSC analysis.

\section{Determination of Cell Death by Apoptosis or Necrosis}

Ped-2E9 cell death by apoptosis or necrosis were determined by using a fluorescence microscopy described previously ${ }^{16,50,51}$ with some modifications. ${ }^{52,53}$ Briefly, a cell staining solution containing $20 \mu \mathrm{g} / \mathrm{ml}$ of $\mathrm{AO}$ and $100 \mu \mathrm{g} / \mathrm{ml}$ of PI (Sigma) was prepared in C-PBS. The collagen-entrapped Ped-2E9 cells (exposed to bacterial cells or toxins, as described in previous sections) were dislodged by collagenase treatment as above. Aliquots of $100 \mu \mathrm{l}$ of cell suspension ( 1 to $2 \times 10^{6} / \mathrm{ml}$ ) was mixed with $100 \mu \mathrm{l}$ of staining solution and analyzed immediately with a fluorescence microscope (Leica, model DMLB, Wetzlar, Germany, with SPOT software, version 4.6.4.2, Diagnostic Instruments, Sterling Heights, MI, USA) using green (for $\mathrm{AO}$ ) and red filters (for PI). The detection of live (L), apoptotic (A) and necrotic (N) cells were carried out in the following manner, green (live), yellow or orange (apoptotic), red (necrotic), both by visual scoring on a hemacytometer and by using image analysis softwares, SPOT, version 4.6.4.2 (images acquisition) and ImageJ v1.38 (NIH, USA) with 'color counter' (v2001) and 'color histogram' plug-ins (v2007) to analyze and enumerate the images.

\section{Statistical Analysis}

Data are expressed as mean \pm standard error of mean (s.e.m.). Statistical analyses of data were performed using GraphPad Prism (version 3.02, GraphPad Software, San Diego, CA, USA). Comparisons of cytotoxicity values between single control and pathogen- and toxin-exposed sample means were made using two-tailed Student's $t$-test. The limit for statistical significance was set at either $P<0.05$ or $P<0.01$ as mentioned.

\section{RESULTS}

Viability of Ped-2E9 Cells in Collagen Microenvironment The collagen matrix microenvironment was fabricated such that the pore diameter of the gel matrix sieve is maintained between 5 and $7 \mu \mathrm{m}$. The cryo-SEM photographs confirmed that a collagen gel concentration of $1.5 \mathrm{mg} / \mathrm{ml}$ optimally achieves the desired pore size.

After encapsulation of the hybridoma cells in the collagen matrix, we determined the viability of the gel-encapsulated Ped-2E9 cells by TB staining and LSC methods. Approximately $82-85 \%$ Ped-2E9 cells remained viable after $48 \mathrm{~h}$ of encapsulation in collagen I matrix (Figure 2). A progressive decrease in viability was observed for the period of 48-96 h. Overall, the viability of the gel-encapsulated cells over a period of first $96 \mathrm{~h}$ was found to be comparable to cells grown in DMEM-PRF with 2.5\% FBS without gel matrices (data not shown).

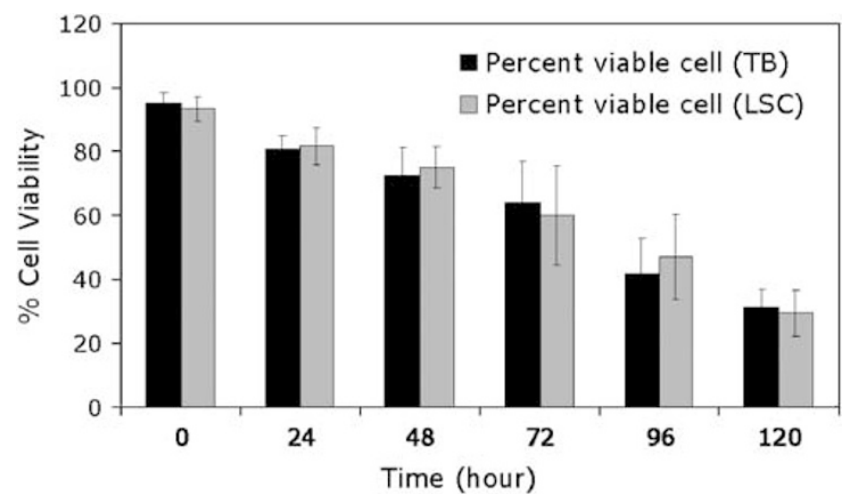

Figure 2 Viability assay of gel-encapsulated Ped-2E9 cells. Viability assessment of the gel-encapsulated Ped-2E9 cells over a period of 5 days (120 h). The percent viable cells count were obtained from Trypan blue dye exclusion method (TB) and by laser scanning cytometry (LSC) as described in the Materials and methods section. Values are presented as mean \pm standard error of mean (s.e.m.) of three experiments carried out in duplicate. 


\section{Pathogen- or Toxin-Induced Cytotoxicity of Gel-Encapsulated Ped-2E9 Cells}

The cytotoxic response of collagen gel-encapsulated hybridoma cells was assessed by assaying ALP released from the damaged hybridoma cells (as described in Materials and Methods). Along with the quantitative enzyme assay, an SEM visualization of Ped-2E9 cell damage and LSC quantification of cytotoxicity based on fluorescence imaging data was also performed.

\section{Measurement of cytotoxicity by ALP release assay}

Collagen-encapsulated Ped-2E9 cells in 48-well plates exposed to either bacterial cells or the toxin preparations were assayed for ALP-based cytotoxicity at two different time points postinfection (Figure 3a). Toxin preparations from pathogenic L. monocytogenes Scott A and B. cereus A926 showed approximately 92 and $98 \%$ cytotoxicity, respectively in $3 \mathrm{~h}$; whereas toxin preparations from nonpathogenic L. innocua F4247 and B. subtilis showed only 2 and $8 \%$ cytotoxicity, respectively (Figure $3 \mathrm{a}$ ). When whole bacterial cells were used (at an approximate MOI of 100 bacteria to 1 Ped-2E9 cell, MOI $=100: 1$ ), the cytotoxicity caused by L. monocytogenes strains Scott A and V7 was found to be approximately 38 and $34 \%$ ( $3 \mathrm{~h}$ postinfection) and 72 and $68 \%$ ( $6 \mathrm{~h}$ postinfection), respectively. In contrast, the nonpathogenic L. innocua F4247 induced only 0.06 or $0.4 \%$ cytotoxicity during the same time period (Figure $3 \mathrm{a}$ ). A visual examination of the 96-well plate also revealed that the intensity in the change of color with pathogenic $v s$ nonpathogenic bacteria or toxins was obvious (data not shown). This observation was confirmed by the direct reading of the plate in a plate reader (Figure 3a). These data are in agreement with our previous study. ${ }^{40}$ Our data also indicate that $B$. cereus $\mathrm{F} 4810$ shows lower hybridoma cytotoxicity (24\%) as compared to B. cereus strains A926 and MS1-9. This difference may be due to strain variation and in agreement with the previous report. ${ }^{37}$

In the present study, we also tested lower MOIs, 50:1 and 10:1. With L. monocytogenes strains Scott A and V7 at MOI of 50:1 and 10:1, at $3 \mathrm{~h}$ postinfection, the cytotoxicity values obtained from treatments of these pathogenic strains were significantly higher $(P<0.05$ or $P<0.01)$ when compared with negative control, nonpathogenic L. innocua F4247 at all postinfection time points ( 3 and $6 \mathrm{~h}$; Figure $3 \mathrm{~b}$ ) but significantly lower $(P<0.05$ or $P<0.01)$ than MOI of $100: 1$.

\section{Measurement of cytotoxicity by LSC studies}

Cellular viability data (as depicted by, PI and Hoechst staining) of the gel-entrapped Ped-2E9 cells $(1,3$ and $6 \mathrm{~h}$ postinfection) obtained from LSC analysis also supported the cytotoxicity data (Figure $3 \mathrm{a}-\mathrm{c}$ ) obtained by ALP assay. When the percent PI-positive Ped-2E9 cell counts, designated as 'LSC (PI +)', were compared with percent TB positive, ' $\mathrm{TB}(+)$ ' they showed a very close numerical values. For example, at 3 and $6 \mathrm{~h}$ postinfection, L. monocytogenes $\mathrm{V} 7$ caused approximately 23 and $81 \%$ of Ped-2E9 cells to become PI positive in LSC, whereas it caused approximately 19 and $75 \%$ of Ped-2E9 cells to become TB-positive (Figure 3c). Similarly, the crude toxin preparations from B. cereus MS1-9 showed very close numerical values of LSC (PI +) and TB $(+)$ (Figure 3c). The percent values of the cytotoxicity (ALP released, calculated as per formula described in the Figure 3a legend) were in agreement with the PI-positive or TB-positive cell numbers (Figure 3c), indicating that higher the cellular death (ie, higher the $\mathrm{PI}+$ and $\mathrm{TB}+$ values), higher is the calculated values of cytotoxicity. Representative laser scanning images (as depicted in Figure 4a-f) show an increase in PI-positive (dead) hybridoma cells (stained red) over PI-negative but Hoechstpositive live cells (blue). While Figure 4 (g-i) are representative scattergrams for numerical analysis of the live and dead counts of cells in the $x-y$ positions as depicted by Hoechst and PI channels.

\section{$3 D$ vs $2 D$ system of Ped-2E9 cell cytotoxicity assay: effect of collagen entrapment and gel matrix pore size (gel concentrations)}

When compared to the conventional 2D Ped-2E9 assay system (without collagen), the 3D collagen matrix system showed similar characteristics (Figure 5a). For example, when L. monocytogenes Scott A cells were used at MOI 100:1, the percent cytotoxicity values in $2 \mathrm{D}$ and $3 \mathrm{D}$ assay formats were 46.2 and 37.9 (at $3 \mathrm{~h}$ postinfection), respectively. At $6 \mathrm{~h}$ postinfection the values were $85.8(2 \mathrm{D})$ and $72.2(3 \mathrm{D})$ (Figure $5 \mathrm{a}$ ). In the case of $B$. cereus toxins, we observed the same trend; for example, at $1 \mathrm{~h}$ postinfection time point, toxin of B. cereus MS1-9 strain showed percent cytotoxicity values of $45.8(2 \mathrm{D})$ and $33.7(3 \mathrm{D})$, at $3 \mathrm{~h}$ postinfection, the same strains showed 97.7 (2D) and 88 (3D) percent cytotoxicity (Figure $5 \mathrm{a}$ ). We found no statistically significant differences $(P>0.05)$ when we compared the percent cytotoxicity values by $2 \mathrm{D} v s 3 \mathrm{D}$ assay formats.

In the present study, we measured the pore size of the collagen matrices with different concentrations of collagen by cryo-nano SEM studies, and it was found that a collagen gel containing $1.5 \mathrm{mg} / \mathrm{ml}$ collagen would have an average gel sieve or pore diameter of about $5-7 \mu \mathrm{m}($ mean $=6 \mu \mathrm{m})$ as described above. Further, we examined the functional suitability of the selected collagen concentration by performing a comparative study with two different collagen concentrations, 2 and $1 \mathrm{mg} / \mathrm{ml}$ at three different postinfection time points (Figure $5 \mathrm{~b}$ ). Our data revealed that when whole bacterial cells were used, the cytotoxicity values obtained from a collagen gel matrix with $1.5 \mathrm{mg} / \mathrm{ml}$ collagen at 3 and $6 \mathrm{~h}$ postinfection time points were significantly $(P<0.05)$ higher than those of the other two gel concentrations (Figure $5 b$ ). When LLO and toxins from B. cereus MS1-9 were tested, we found no significant difference $(P>0.05)$ in cytotoxicity values with 1.5 or $2 \mathrm{mg} / \mathrm{ml}$ collagen gels at 1,3 and $6 \mathrm{~h}$ 

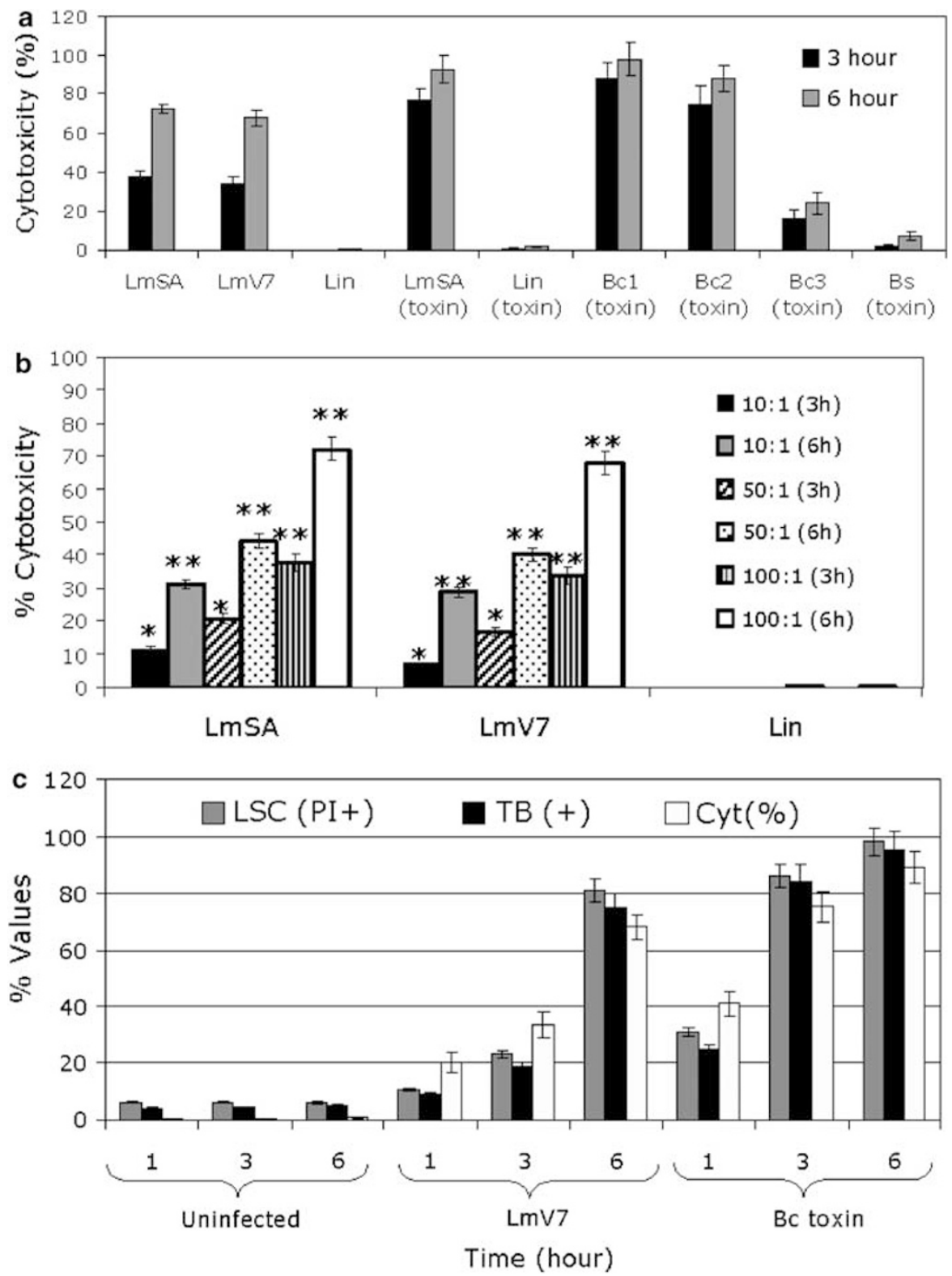

Figure 3 Assessment of Ped-2E9 cell cytotoxicity induced by pathogenic Listeria or Bacillus toxin. (a) Quantitative values of the cytotoxicity were calculated by alkaline phosphatase (ALP) released from damaged Ped-2E9 cells resulted from exposure to bacteria cells or toxin preparations (tox). The $x$ axis legends are: LmSA, L. monocytogenes Scott A; LmV7, L. monocytogenes V7; Lin, L. innocua F4247; LmSA (tox), L. monocytogenes Scott A toxin; Lin (tox), L. innocua F4247 toxin preparation; Bc1, B. cereus A926; Bc2, B. cereus MS1-9; Bc3, B. cereus F4810 and Bs, B. subtilis. The percent cytotoxicity was reported based on ALP release which was calculated using formula:

$$
\left[A_{\text {experimental value }}-A_{\text {control (media) }}\right] \div\left[A_{\text {control (Triton-X) }}-A_{\text {control (media) }}\right] \times 100 \text {. }
$$

Values are average of two separate experiments carried out in duplicate; values are presented as mean \pm standard error of mean (s.e.m.). (b) Comparisons of Ped-2E9 cell cytotoxicity induced by Listeria whole cells infected at different multiplicity of infections (MOIs). Cytotoxicity assessment of three different MOls, 10:1, 50:1 and 100:1 at two different postinfection time points ( 3 and $6 \mathrm{~h}$ ). The percent cytotoxicity values (ALP assay) were calculated by the above mentioned formula. Columns, mean; bars, s.e.m. ${ }^{\star P}<0.05 ;{ }^{*} P<0.01$. (c) Quantitative comparisons of pathogen or toxin induced Ped-2E9 cell cytotoxicity by three methods, laser scanning cytometry (LSC), Typan blue dye exclusion (TB) and ALP release cytotoxicity assay. On $y$ axis, percentage values of gelentrapped PI-positive Ped-2E9 cells obtained from LSC analysis, reported as LSC (PI +); percent values of Trypan blue-positive Ped-2E9 cell, designated as TB (+); and percent cytotoxicity values (ALP assay) as calculated by the above mentioned formula and designated as Cyt (\%). The $x$ axis legends are: uninfected, Ped-2E9 cells which are not infected with pathogens or toxin; Lm V7, L. monocytogenes V7; and Bc toxin, crude toxin preparation from B. cereus MS1-9. The measurements were carried out and reported at 1, 3 and $6 \mathrm{~h}$ postinfection. Values are presented as mean \pm standard error of mean (s.e.m.) of three experiments carried out in duplicate. 

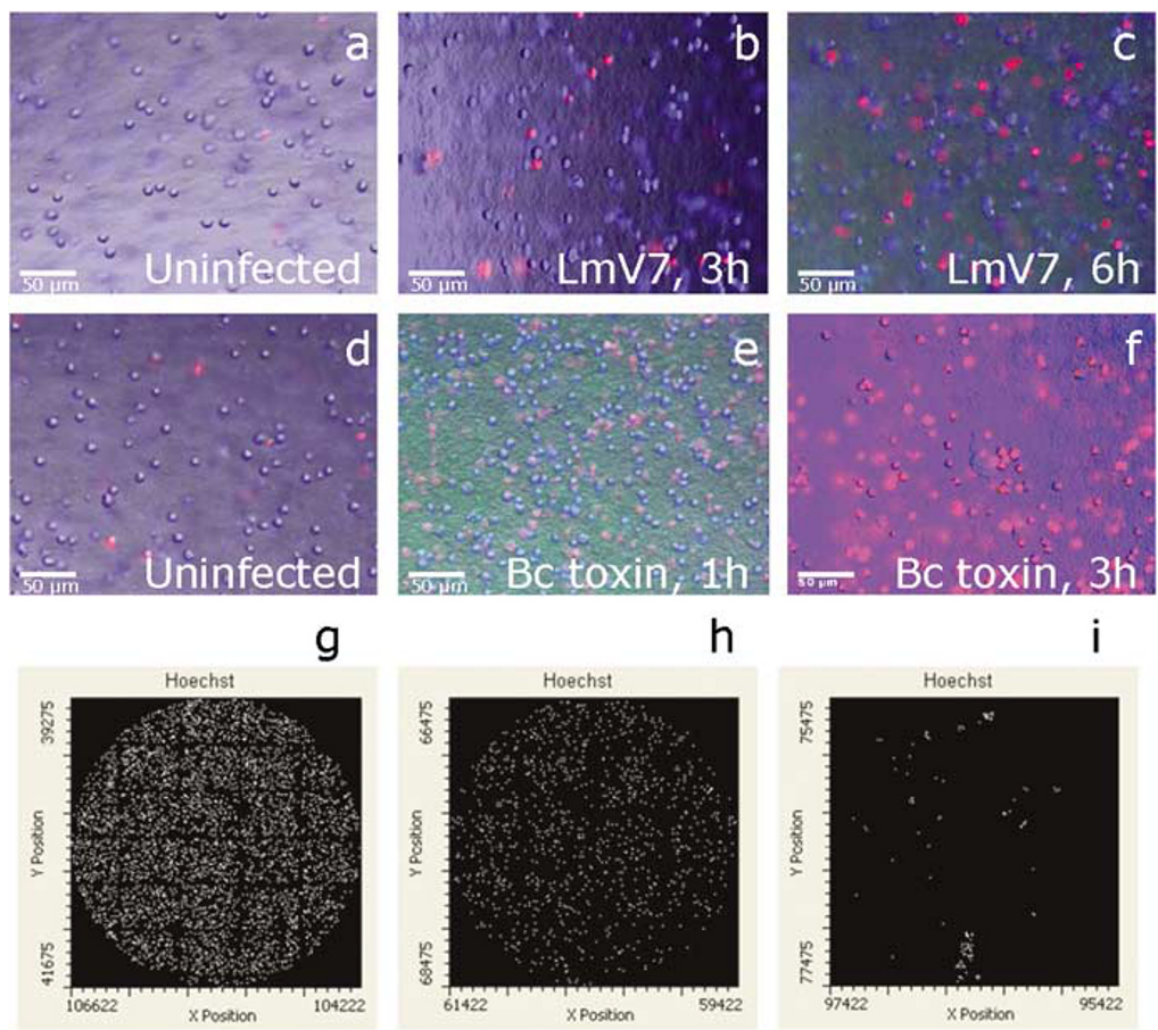

PI

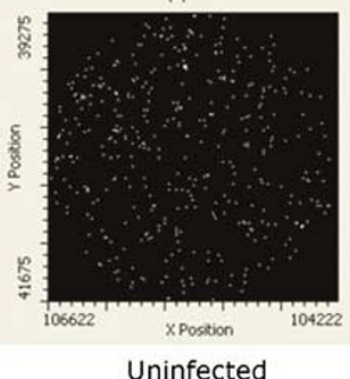

Uninfected

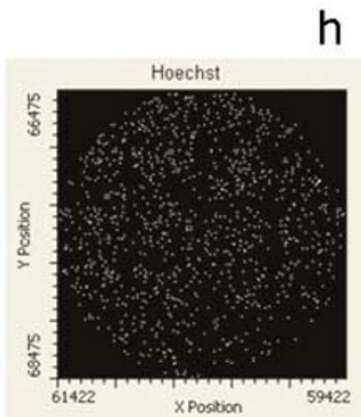

$\mathrm{PI}$

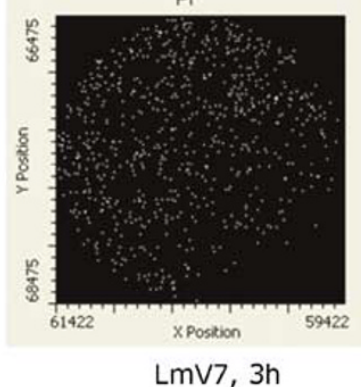

LmV7, 3h

h

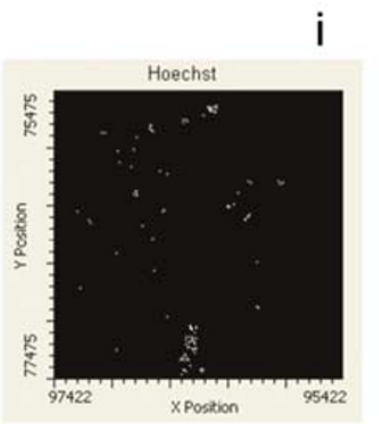

PI

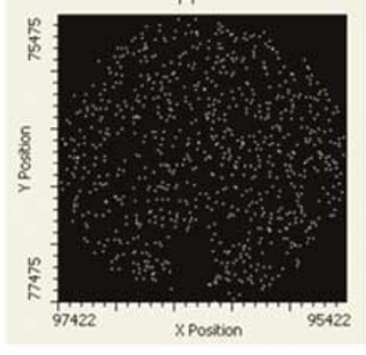

Bc toxin, 3h
Figure 4 Representative laser scanning cytometry images of Ped-2E9 cells entrapped in gel. The images (a-f) are shown as merged and virtually colored images of blue (Hoechst 33342, 405 excitation line) and red (PI, 488 excitation line) as obtained by the photomultiplier of the iCys LSC. The blue cells were counted as 'live' whereas the red cells were counted as 'dead'. (a) Control, uninfected Ped-2E9 cells; (b) and (c) infected with L. monocytogenes V7 cells (approximate multiplicity of infection of 100 bacterial cells to 1 Ped-2E9 cell) 3 and $6 \mathrm{~h}$ postinfection, respectively; (d) control (without toxin); (e and $\mathbf{f}$ ) infected with crude toxin from B. cereus MS1-9 (approximate total protein concentration of the crude toxin preparation was $20 \mu \mathrm{g} / \mathrm{ml}$, and used in 1:2 dilution) 1 and $3 \mathrm{~h}$ postinfection, respectively. The scattergrams (g-i) represent the $x-y$ positions of cells identified as live (as indicated by the presence of a Hoechst signal, upper row) and cells identified as dead (as indicated by propidium iodide signal, lower row); (g) control cells (high viability) (h) infected with L. monocytogenes V7 cells, $3 \mathrm{~h}$ postinfection (medium viability); (i) infected with crude toxin from $B$. cereus MS1-9, $3 \mathrm{~h}$ postinfection (low viability). postinfection time point, but, the cytotoxicity values with lower gel concentrations $(1 \mathrm{mg} / \mathrm{ml})$ were significantly $(P<0.05)$ low at the same time points (Figure $5 \mathrm{~b})$, and this was attributed to the fact that some Ped-2E9 cells may have been lost during washing and medium replenishment step (data not shown, the cell retention within the collagen matrix was enumerated by cell count methods as described earlier).

\section{Visualization of Ped-2E9 cell membrane damage by pathogens} or toxins and cytotoxicity by SEM study

The time dependence of the pathogen and toxin induced damage of the gel-encapsulated Ped-2E9 cells were evident by SEM images (Figure 6). A progressive damage of the cell membrane can be observed with the increase of the infection time. Figure $6 \mathrm{~b}$ depicts the attachment of L. monocytogenes V7 cells on gel-encapsulated Ped-2E9 cells, while a complete disruption of cell membrane and morphology can be observed at $3 \mathrm{~h}$ postinfection with B. cereus MS1-9 toxin (Figure 6f).

\section{Assessment of apoptosis vs necrosis of Ped-2E9 cells by pathogens or toxins}

The results of the apoptosis and necrosis analysis revealed that exposure to viable L. monocytogenes Scott A cells caused apoptosis in approximately half (50\%) of the Ped-2E9 cell population (Figure $7 \mathrm{~b}$ ), while about $84 \%$ Ped-2E9 cells underwent necrotic death when exposed to B. cereus MS1-9 toxin (Figure 7d). LLO from L. monocytogenes Scott A induced approximately 63\% necrotic and 26\% apoptotic cell death (Figure 7c). In control cells (Figure 7a), a majority of Ped-2E9 cells were viable (90\%) and 7\% cells were necrotic and only $3 \%$ were apoptotic. The propensity of Ped-2E9 cells to undergo apoptotic cell death when exposed to Listeria cells as revealed by the current study is in agreement with previous observations. ${ }^{16,54}$ 

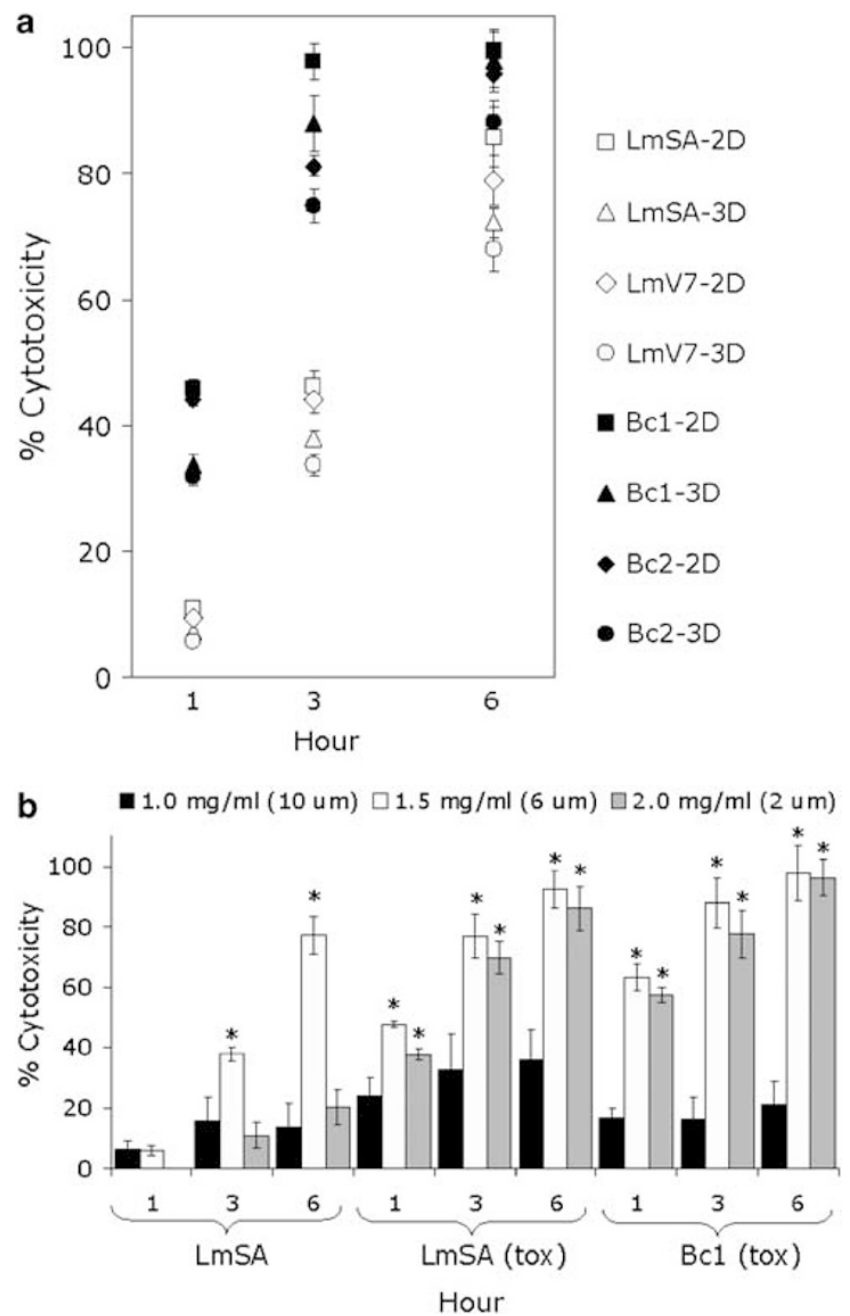

Figure 5 Three-dimensional (3D) vs two-dimensional (2D) system of Ped2E9 cell cytotoxicity assay-effect of collagen entrapment and gel matrix pore size (gel concentrations). (a) Comparison of percent cytotoxicity values in 3D culture system with 2D controls in three different time points, 1, 3 and $6 \mathrm{~h}$. The percent cytotoxicity values (alkaline phosphatase (ALP) assay) were calculated by the above mentioned formula. The legends are: LmSA, L. monocytogenes Scott A cells; LmV7, L. monocytogenes V7 cells; Bc1, $B$. cereus A926 toxin and $B C 2, B$. cereus MS1-9 toxin. The suffixes, 2D, two dimensional formats without the gel; 3D, three dimensional formats with collagen gel. Bars, s.e.m. (b) Three different collagen concentrations were tested as encapsulating matrices for Ped-2E9 cells. The $x$ axis legends are as follows: LmSA, L. monocytogenes Scott A; LmSA (tox), L. monocytogenes Scott $A$ toxin; $B C 1$ (tox), toxin from B. cereus MS1-9. The values in parenthesis is the approximate diameter of the collagen sieve (pore size in $\mu \mathrm{m}$ ) as estimated by scanning electron microscopy (described in Materials and Methods section). The percent cytotoxicity values (ALP assay) were calculated by the above-mentioned formula. Columns, mean; bars, s.e.m. ${ }^{\star} P<0.05$.

\section{DISCUSSION}

The advent of biosensor-based technology has created an immense opportunity to probe various biochemical and cellular interactions more vividly. Cell-based sensors are often preferred to other kinds of recognition system as living cells best mimic a physiological situation. ${ }^{9,55}$ Due to the inherent advantages of CBBs in screening of 'active' (eg, live pathogenic bacteria) vs 'nonactive' (eg, heat killed pathogenic bacteria) biological entities, the application of this types of biosensors are increasing rapidly, specially in clinical and environmental diagnostics, food safety, biosecurity and in advanced pathological applications. ${ }^{4,5,9,10,16}$

In our study, we have shown that a B-cell hybridoma, which normally grows in suspension, can be immobilized in collagen matrices. Further, we have also shown qualitatively as well as quantitatively that these gel-encapsulated cells can be effectively used as a sensor device to detect the presence of pathogenic microorganisms or their toxins. This study also incorporates a novel method, used for first time to determine the viability of gel-encapsulated cells in situ using a LSCbased technique. This application of hybridoma cells instigates further studies to improve the detection limit by modulating collagen concentrations or altering the encapsulation procedures.

In the present study, while encapsulating the mammalian cells in collagen matrix, we found that there is a progressive decrease in cell viability for the period of 48-96 h (Figure 2). This decrease could probably be attributed to nutrient limitation, accumulation of toxic metabolites or diffusion limitation in the gel matrix. ${ }^{56,57}$ Second, when the cytotoxicity data collected, after $3 \mathrm{~h}$ of exposure to toxin or whole bacterial cells, showed lower cytotoxicity value when compared with $6 \mathrm{~h}$ postinfection values (Figure 3a). It was also observed that the cytotoxicity values were slightly lower but not statistically significant in 3D collagen-entrapped assay format as compared to $2 \mathrm{D}$ control without collagen (Figure 5a). This may be due to the slower diffusion of toxin molecules or released enzymes and substrates in the gel as compared to the liquid system. ${ }^{57}$ Moreover, the gel matrix sieve size is a limiting factor for bacterial entry (Figure 5b). The requirement of a longer postinfection incubation time with intact bacterial cells, and the lower concentrations of detectable ALP may be attributed to a collagen concentration, which may hinder bacterial passage in the gel matrices and to reach to hybridoma cells. Thus, we indirectly quantified the effect of 3D gel matrix on the cytotoxicity by comparing cytotoxicity data with 2D system in absence of collagen matrix (Figure 5a). The observations made in the comparative $2 \mathrm{D}$ and $3 \mathrm{D}$ systems revealed a slight decrease in cytotoxicity values, although statistically insignificant, for 3D system, is thought to be due to possible diffusion limitation (Figure 5a). This diffusion limitation can be attributed to the entry of bacteria and toxin into the gel matrices, the interaction of bacteria and toxin with the Ped-2E9 cells and thereby causing cell damage, and the release of cellular ALP and its diffusion out of gel matrix.

Overall, our data suggest that B-lymphocyte origin Ped2E9 hybridoma cell line can effectively be encapsulated in the collagen matrix. The advantage of using collagen type $\mathrm{I}$ is that it is readily available and is used widely by many investigators and has been standardized as a gel scaffold. ${ }^{31-34}$ Both collagen I and collagen II are fibrillar collagens and share high degree 


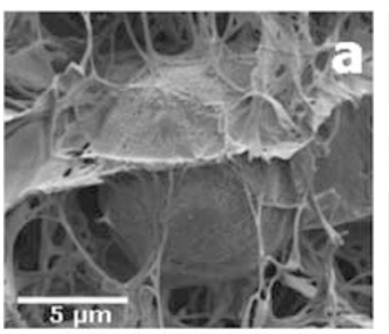

Uninfected Ped-2E9 cell

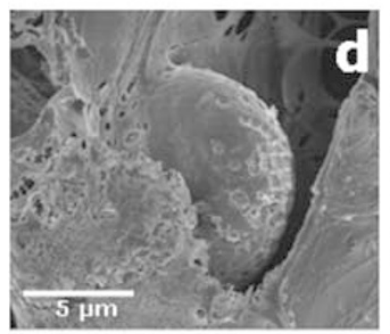

Infected Bc toxin (1h)

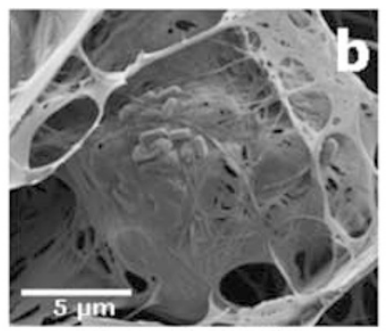

Infected, LmV7 (3h)

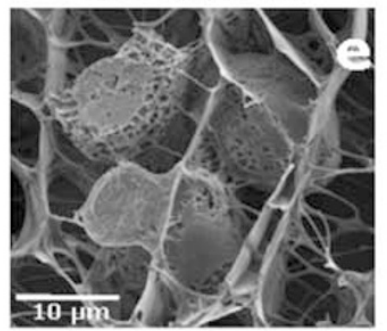

Infected, LLO (3h)

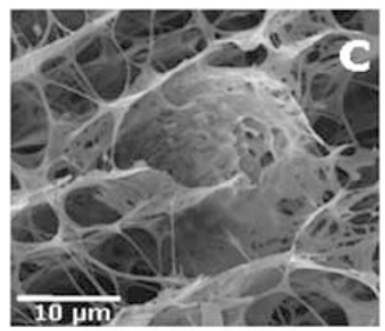

Infected, LmV7 (6h)

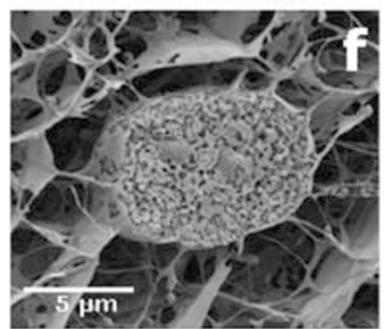

Infected, Bc toxin ( $3 \mathrm{~h}$ )
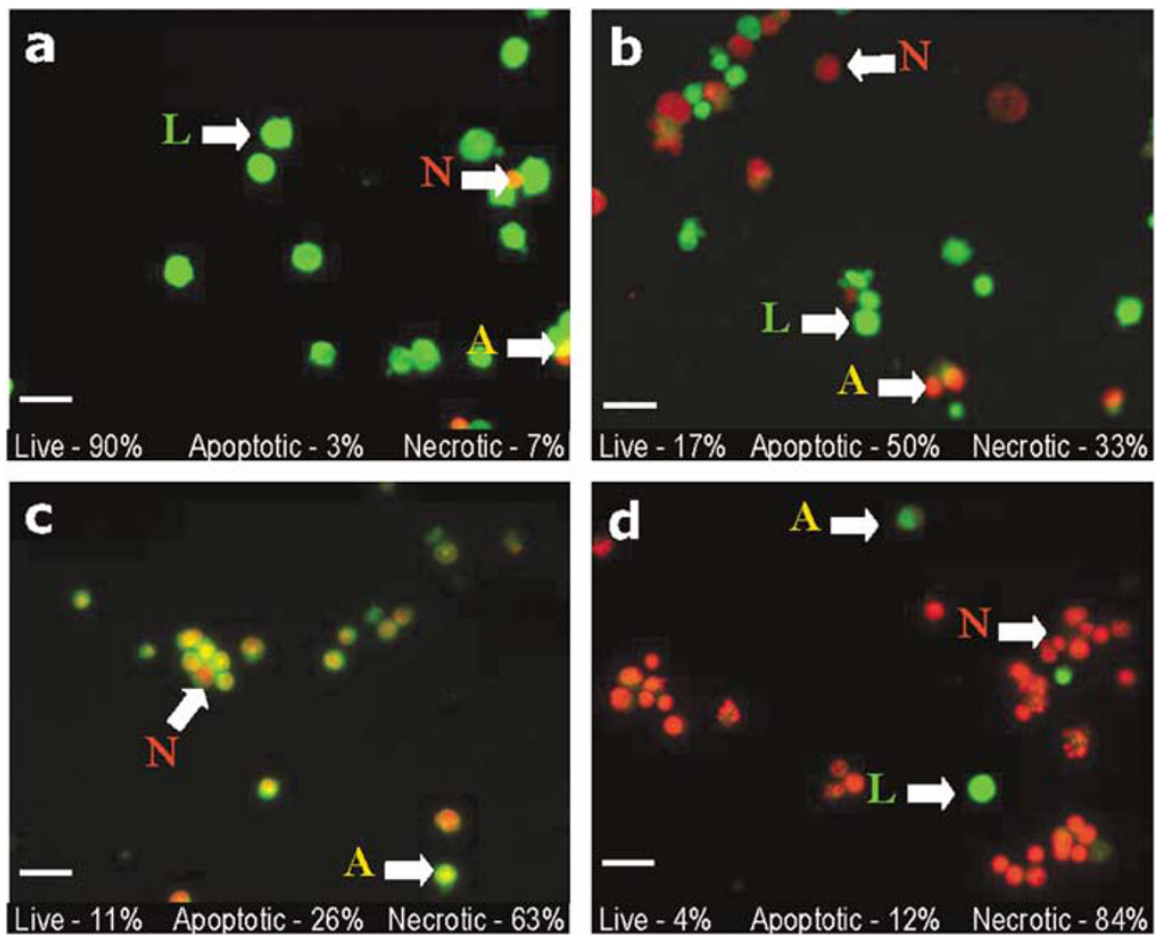

Figure 6 The cryo-SEM images of pathogenor toxin-induced damage of Ped-2E9 cells in collagen gel matrix. (a) Uninfected Ped-2E9 cell encapsulated in collagen gel; (b and c) depict the bacteria and mammalian cell interactions; (d-f) show the damage of Ped-2E9 cells upon exposure to toxins from $B$. cereus MS1-9 and listeriolysin O (LLO) of L. monocytogenes Scott A in different time intervals.

Figure 7 Quantitative analysis of apoptotic and necrotic Ped-2E9 cells induced by pathogenic Listeria or Bacillus toxin as depicted by intake of fluorescence dyes acridine orange (AO, green) and propidium iodide ( $\mathrm{PI}, \mathrm{red}$ ). Cells were dislodged from collagen matrices by treating with collagenase and were mixed immediately with dye solutions (Materials and methods section). Fluorescence micrograph images (merged images of green and red panel) are from different treatments such as (a) uninfected Ped2E9 cells; (b) L. monocytogenes Scott A whole cells; (c) listeriolysin O (LLO) of L. monocytogenes Scott A; (d) toxins from B. cereus MS1-9. Green fluorescence $(A O)$ indicates viable or live cell population (marked as $\mathrm{L}$ ), red fluorescence (PI) indicates dead cells (necrotic, marked as N), and yellow or orange fluorescence (merger of $\mathrm{AO}+\mathrm{PI}$ ) indicates either proapoptotic or late apoptotic cells (marked as A). An average cell count of 400 ( $n=400)$ per sample per treatment was counted manually (hemacytometer) and by ImageJ software. Values reported are mean of three independent experiments. Bar $=20 \mu \mathrm{m}$. of similarities in amino-acid sequence and physiological properties $^{31-34}$ further aided in our decision to use collagen type I. We also used Ultra Pure ${ }^{\mathrm{TM}}$ agarose (Invitrogen) as an entrapment agent, but the results were unsatisfactory. Agarose (0.7-1.5\%)-encapsulated Ped-2E9 cell viability was very poor; greater than $75 \%$ of the Ped-2E9 cells were dead after $24 \mathrm{~h}$ of encapsulation, and $98-100 \%$ cell death was observed after $48 \mathrm{~h}$ (data not shown). Thus, agarose was not considered for further evaluation.
Pathogenic microorganisms or toxins have already been shown to cause membrane disruption and apoptotic cell death in lymphocytes ${ }^{58}$ and in B cells. ${ }^{54}$ Previously, we have shown Listeria-mediated apoptotic cell death of Ped-2E9 cell, B-cell origin, ${ }^{54}$ which is verified further in this study (Figure 7). As revealed by the SEM images (Figure 6), the cell membrane damage of gel-encapsulated Ped-2E9 cells caused by bacterial cells or toxins show close similarity with our earlier studies, ${ }^{4,54}$ indicating that, the cellular and 
physiological characteristics of both the Ped-2E9 cells and the pathogens remained unaltered in a collagen gel microenvironment. This finding is particularly important as the viability of mammalian cells after immobilization in biocompatible matrices is the key factor for cell-based assays. ${ }^{15,27,32,35}$

In the present study, we have shown that Ped-2E9 cells (which grow in suspension) can be immobilized threedimensionally into a biocompatible collagen gel matrix without losing their biological and physiological properties of sensitivity to pathogenic Listeria and Bacillus cells or toxins. This 3D immobilization also reduces the normal 2D assay steps such as centrifugation, critically important for the integration of these cell types in a biosensor platform. Further, we speculate that, this immobilization technique will pave the way for convenient designs of future CBBs and easy to use cell-based assay systems. Finally, we conclude that gelimmobilized mammalian cells have a tremendous potential to be used as cell-based sensing system to interrogate with pathogenic organisms, toxins and toxic chemicals for food safety, biosecurity, clinical and pathological applications.

\section{ACKNOWLEDGEMENT}

We thank Debra M Sherman of Life Science Microscopy Facility at Purdue University for cryo-SEM analysis and Dr Shantanu Sur, Lab for Memory \& Learning, Brain Sc Inst, RIKEN, Japan for his advice on collagen matrix preparations. A part of this research was supported by the US Department of Agriculture (USDA) - National Research Initiative (NRI) Grant no. 200535603-16338 and through a cooperative agreement with the Agricultural Research Service of the USDA project no. 1935-42000-035, the Center for Food Safety Engineering at Purdue University.

1. Butcher EC, Berg EL, Kunkel EJ. Systems biology in drug discovery. Nat Biotechnol 2004;22:1253-1259.

2. Fairey ER, Bottein Dechraoui MY, Sheets MF, et al. Modification of the cell based assay for brevetoxins using human cardiac voltage dependent sodium channels expressed in HEK-293 cells. Biosens Bioelectron 2001;16:579-586.

3. Matsue T, Shiku H. Electrochemical microbiosensors using living cells. Electrochemistry 2006;74:107-113.

4. Michelini $E$, Leskinen $P$, Virta $M$, et al. A new recombinant cell-based bioluminescent assay for sensitive androgen-like compound detection. Biosens Bioelectron 2005;20:2261-2267.

5. Rawson DM, Willmer AJ, Turner AP. Whole-cell biosensors for environmental monitoring. Biosensors 1989;4:299-311.

6. Aravanis AM, DeBusschere BD, Chruscinski AJ, et al. A genetically engineered cell-based biosensor for functional classification of agents. Biosens Bioelectron 2001;16:571-577.

7. Gray SA, Kusel JK, Shaffer KM, et al. Design and demonstration of an automated cell-based biosensor. Biosens Bioelectron 2001;16:535-542.

8. Rider TH, Petrovick MS, Nargi FE, et al. A B cell-based sensor for rapid identification of pathogens. Science 2003;301:213-215.

9. Stenger DA, Gross GW, Keefer EW, et al. Detection of physiologically active compounds using cell-based biosensors. Trends Biotechnol 2001;19:304-309.

10. Ziegler C. Cell-based biosensors. Fresenius J Anal Chem 2000;366: 552-559.

11. Relman DA. Shedding light on microbial detection. N Engl J Med 2003;349:2162-2163.

12. Neufeld T, Biran D, Popovtzer R, et al. Genetically engineered pfabA pfabR bacteria: an electrochemical whole cell biosensor for detection of water toxicity. Anal Chem 2006;78:4952-4956.
13. Fine $T$, Leskinen $P$, Isobe $T$, et al. Luminescent yeast cells entrapped in hydrogels for estrogenic endocrine disrupting chemical biodetection. Biosens Bioelectron 2006;21:2263-2269.

14. May KM, Wang Y, Bachas LG, et al. Development of a whole-cell-based biosensor for detecting histamine as a model toxin. Anal Chem 2004;76:4156-4161.

15. Meng $\mathrm{Y}$, Kasai $\mathrm{A}$, Hiramatsu $\mathrm{N}$, et al. Continuous, noninvasive monitoring of local microscopic inflammation using a genetically engineered cell-based biosensor. Lab Invest 2005;85:1429-1439.

16. Banerjee P, Morgan MT, Rickus JL, et al. Hybridoma Ped-2E9 cells cultured under modified conditions can sensitively detect Listeria monocytogenes and Bacillus cereus. Appl Microbiol Biotechnol 2007;73:1423-1434.

17. Evans ND, Gnudi L, Rolinski OJ, et al. Non-invasive glucose monitoring by $\mathrm{NAD}(\mathrm{P}) \mathrm{H}$ autofluorescence spectroscopy in fibroblasts and adipocytes: a model for skin glucose sensing. Diabetes Technol Ther 2003;5:807-816.

18. Evans ND, Gnudi L, Rolinski OJ, et al. Glucose-dependent changes in $\mathrm{NAD}(\mathrm{P}) \mathrm{H}$-related fluorescence lifetime of adipocytes and fibroblasts in vitro: potential for non-invasive glucose sensing in diabetes mellitus. J Photochem Photobiol B 2005;80:122-129.

19. Gholmieh G, Courellis S, Fakheri S, et al. Detection and classification of neurotoxins using a novel short-term plasticity quantification method. Biosens Bioelectron 2003;18:1467-1478.

20. Ghosh S, Spagnoli GC, Martin I, et al. Three-dimensional culture of melanoma cells profoundly affects gene expression profile: a high density oligonucleotide array study. J Cell Physiol 2005;204:522-531.

21. Britland S, Clark P, Connolly $\mathrm{P}$, et al. Micropatterned substratum adhesiveness: a model for morphogenetic cues controlling cell behavior. Exp Cell Res 1992;198:124-129.

22. Britland $\mathrm{S}$, Perez-Arnaud E, Clark $\mathrm{P}$, et al. Micropatterning proteins and synthetic peptides on solid supports: a novel application for microelectronics fabrication technology. Biotechnol Prog 1992;8:155-160.

23. Clark P, Connolly P, Moores GR. Cell guidance by micropatterned adhesiveness in vitro. J Cell Sci 1992;103:287-292.

24. Pizziconi VB, Page DL. A cell-based immunobiosensor with engineered molecular recognition-Part I: design feasibility. Biosens Bioelectron 1997;12:287-299.

25. Cabodi M, Choi NW, Gleghorn JP, et al. A microfluidic biomaterial. J Am Chem Soc 2005;127:13788-13789.

26. Nassif $\mathrm{N}$, Bouvet $\mathrm{O}$, Noelle Rager $\mathrm{M}$, et al. Living bacteria in silica gels. Nat Mater 2002;1:42-44.

27. Quinn CA, Connor RE, Heller A. Biocompatible, glucose-permeable hydrogel for in situ coating of implantable biosensors. Biomaterials 1997;18:1665-1670.

28. Yamaoka $\mathrm{H}$, Asato $\mathrm{H}$, Ogasawara $\mathrm{T}$, et al. Cartilage tissue engineering chondrocytes embedded in using human auricular different hydrogel materials. J Biomed Mater Res A 2006;78A:1-11.

29. Gentleman E, Lay AN, Dickerson DA, et al. Mechanical characterization of collagen fibers and scaffolds for tissue engineering. Biomaterials 2003;24:3805-3813.

30. Mardilovich A, Craig JA, McCammon MQ, et al. Design of a novel fibronectin-mimetic peptide-amphiphile for functionalized biomaterials. Langmuir 2006;22:3259-3264.

31. Cukierman E, Pankov R, Yamada KM. Cell interactions with threedimensional matrices. Curr Opin Cell Biol 2002;14:633-639.

32. Patino MG, Neiders ME, Andreana $\mathrm{S}$, et al. Collagen: an overview. Implant Dent 2002;11:280-285.

33. Krewson CE, Chung SW, Dai WG, et al. Cell-aggregation and Neurite growth in gels of extracellular-matrix molecules. Biotechnol Bioeng 1994;43:555-562.

34. O'Connor SM, Andreadis JD, Shaffer KM, et al. Immobilization of neural cells in three-dimensional matrices for biosensor applications. Biosens Bioelectron 2000;14:871-881.

35. Desai A, Kisaalita WS, Keith C, et al. Human neuroblastoma (SH-SY5Y) cell culture and differentiation in 3-D collagen hydrogels for cell-based biosensing. Biosens Bioelectron 2006;21:1483-1492.

36. Mao C, Kisaalita WS. Characterization of 3-D collagen hydrogels for functional cell-based biosensing. Biosens Bioelectron 2004;19:1075-1088.

37. Gray KM, Banada PP, O'Neal E, et al. Rapid Ped-2E9 cell-based cytotoxicity analysis and genotyping of Bacillus species. J Clin Microbiol 2005;43:5865-5872. 
38. Gray KM, Bhunia AK. Specific detection of cytopathogenic Listeria monocytogenes using a two-step method of immunoseparation and cytotoxicity analysis. J Microbiol Methods 2005;60:259-268.

39. Bhunia AK, Steele PJ, Westbrook DG, et al. A six-hour in vitro virulence assay for Listeria monocytogenes using myeloma and hybridoma cells from murine and human sources. Microb Pathog 1994;16:99-110.

40. Bhunia AK, Westbrook DG. Alkaline phosphatase release assay to determine cytotoxicity for Listeria species. Lett Appl Microbiol 1998;26:305-310.

41. Bhunia AK, Westbrook DG, Story $R$, et al. Frozen stored murine hybridoma cells can be used to determine the virulence of Listeria monocytogenes. J Clin Microbiol 1995;33:3349-3351.

42. Farber JM, Speirs JI. Potential use of continuous cell lines to distinguish between pathogenic and nonpathogenic Listeria spp. J Clin Microbiol 1987;25:1463-1466.

43. Gracieux $\mathrm{P}$, Roche $\mathrm{SM}$, Pardon $\mathrm{P}$, et al. Hypovirulent Listeria monocytogenes strains are less frequently recovered than virulent strains on PALCAM and Rapid' L. mono media. Int J Food Microbiol 2003;83:133-145.

44. Pine L, Kathariou S, Quinn F, et al. Cytopathogenic effects in enterocytelike Caco-2 cells differentiate virulent from avirulent Listeria strains. J Clin Microbiol 1991;29:990-996.

45. Roche SM, Velge $P$, Bottreau $E$, et al. Assessment of the virulence of Listeria monocytogenes: agreement between a plaque-forming assay with HT-29 cells and infection of immunocompetent mice. Int J Food Microbiol 2001;68:33-44.

46. Shroyer ML, Bhunia AK. Development of a rapid 1-h fluorescencebased cytotoxicity assay for Listeria species. J Microbiol Methods 2003;55:35-40.

47. Bhunia AK, Feng X. Examination of cytopathic effect and apoptosis in Listeria monocytogenes-infected hybridoma B-lymphocyte (Ped-2E9) line in vitro. J Microbiol Biotechnol 1999;9:398-403.
48. Mittag A, Lenz D, Gerstner AO, et al. Hyperchromatic cytometry principles for cytomics using slide based cytometry. Cytometry A 2006;69:691-703.

49. Mosch B, Mittag A, Lenz D, et al. Laser scanning cytometry in human brain slices. Cytometry A 2006;69:135-138.

50. Fassnacht $D$, Rössing $S$, Ghaussy $N$, et al. Influence of non-essential amino acids on apoptotic and necrotic death of mouse hybridoma cells in batch cultures. Biotechnol Lett 1997;19:35-38.

51. Simpson $\mathrm{NH}$, Singh RP, Emery AN, et al. Bcl-2 over-expression reduces growth rate and prolongs $\mathrm{G} 1$ phase in continuous chemostat cultures of hybridoma cells. Biotechnol Bioeng 1999;64:174-186.

52. Goodyear-Bruch C, Simon K, Hall S, et al. Comparison of a visual to a computer-assisted technique for detecting apoptosis. Biol Res Nurs 2005;6:180-186.

53. Ribble D, Goldstein NB, Norris DA, et al. A simple technique for quantifying apoptosis in 96-well plates. BMC Biotechnol 2005;5:12.

54. Menon A, Shroyer ML, Wampler JL, et al. In vitro study of Listeria monocytogenes infection to murine primary and human transformed $\mathrm{B}$ cells. Comp Immunol Microbiol Infect Dis 2003;26:157-174.

55. Park TH, Shuler ML. Integration of cell culture and microfabrication technology. Biotechnol Prog 2003;19:243-253.

56. Banik GG, Heath CA. High-density hybridoma perfusion culture. Limitation vs inhibition. Appl Biochem Biotechnol 1996;61:211-229.

57. Wu DQ, Zhang GL, Shen $C$, et al. Evaluation of diffusion in gel entrapment cell culture within hollow fibers. World J Gastroenterol 2005;11:1599-1604.

58. Carrero JA, Unanue ER. Lymphocyte apoptosis as an immune subversion strategy of microbial pathogens. Trends Immunol 2006;27:497-503. 